DOI: 10.12731/2227-930X-2016-2-137-151

\title{
PROGRAM AND GOAL-ORIENTED DEVELOPMENT OF THE MUNICIPALITY
}

\section{Yankovskaya $\mathbf{V}$. .}

The article presents weaknesses of the Socio-Economic Development Program (SED) with further optimization and formulation of the strategy. Dubna SED is studied by means of qualitative modification of the system of indicators used to assess SED Program priorities. Qualitative analysis of the Program of Socio-Economic Development of naukograd Dubna 2011-2015 enabled to assess its opportunities and prospects. Theoretical aspects of planning as a function of local government have been studied while analyzing activity of the municipality. Analysis of target values of key social indicators in the town for 2012 and 2014 finally resulted in a vivid picture of qualitative modification of the system of indicators for assessing SED Program priorities in this municipality.

The research was based on actual materials referring to Dubna SED, namely, target programs, forecasts, development strategy, and the Mayor's reports on local government activity.

Keywords: program; SED; municipality; performance indicators; planning principles.

\section{ПРОГРАММНО-ЦЕЛЕВОЕ РАЗВИТИЕ МУНИЦИПАЛИТЕТА}

\section{Янковская В.В.}

Сегодня осуществляется попытка выявить слабые стороны Программы сочииально-экономического развития (СЭР), с последующей оптимизацией и разработкой стратегии, рассматривает- 
ся соииально-экономическое развитие города Дубна, посредством качественной модификации системы показателей, используемых для оченки приоритетности ичелей программы СЭР. Качественный анализ Программы сочиально-экономического развития наукограда Дубна на 2011-2015 г2. позволил оченить её возможности и перспективы. В ходе анализа деятельности муниципалитета исследовались и теоретические аспекты планирования как функции органов местного самоуправления. Анализ контрольных значений основных показателей социально-экономического развития г. Дубны за 2012 и 2014 гг., дал в конечном итоге наглядную картину качественной модификачии системы показателей для оченки приоритетности целей программы СЭР данного муниципалитета.

Целью статьи является выявление слабых сторон Программы СЭР, с последующей оптимизащчей и разработкой стратегии. На примере социально-экономическое развития подмосковного города Дубна.

Исследования проводились на основе фактических материалов о сочиально-экономическом развитии г. Дубны, в частности изелевых программ, прогнозов, стратегии развития, отчетов Главы города о деятельности органов местного самоуправления.

Ключевые слова: программа; сочиильно-экономическое развитие; муниципалитет; показатели эффективности; принщипь планирования.

In Russia, as in a federal state, challenges of government control of regional development are met at a federal and regional level.

The federal subjects of Russia control development of their territories, first of all, elaborating and implementing SED strategies and programs within their powers.

Planning is one of the main functions of the local government. Planning determines development goals, ways and methods, and inspection standards needed to achieve these goals. 
Principles of municipal planning are as follows:

1. Deputies, administrative employees, specialists and experts are to be involved in planning. It enables to set the priorities.

2. Planning is a recurrent process. While planning, it's necessary to take into account results of the previous planning period and, if necessary, to make adjustments.

3. Possible changes in "external environment", assuming changes in the plan, are to be considered at planning.

4. Planning involves "horizontal" coordination. "Vertical" integration is effected when local government authorities participate in execution of different federal and regional programs.

5. Arrangement of necessary conditions for plan fulfillment.

6. Scientific character of planning.

7. Process of municipal planning is to be controlled by the special body (planning committee), formed from representative of different departments chaired by the head of administration or his deputy [8].

At the moment, medium-term planning is the basis of the SED municipal planning. Municipal budget is enacted for 1 year; financial plan and SED forecast are made for 3 years.

Town goal-oriented programs are set up for 3-5 years. Today, two long-term federal programs are effective in the town: Naukograd Development Program for 25 years and Program for Establishment of the Technology Innovative SEZ since 2007 to 2017 is revised.

Now, the Program of Socio-Economic Development of Dubna as a naukograd of the Russian Federation 2012-2016 is implemented in the town. For the last four years the program has not been essentially amended.

The author thinks that the regional SED strategy is to be composed of two main blocks. The first block (the strategy) means the most important long-term goals and priorities of regional SED (10-15 years), as well as their substantiation. The second block means the regional SED program for the next planned period (five years). 
In S.A. Nekhaev's view, the president of the network holding WEB-PLAN Group, regional SED programs, elaborated and implemented today according to the Federal Law of the Russian Federation, have some methodological miscalculations that do not enable to make the most of the regional potential and the whole variety of existing investment vehicles, technologies and instruments, and thus, in fact cannot encourage additional investments to the region and cannot use extra-budgetary resources for financing regional programs [3].

V.V. Kukushkina, the author of the monograph Models and Methods of Strategic Planning and Development, underlines the following methodological approaches used to elaborate SED forecasts, strategic programs and plans [2]: system-comprehensive approach; system-program approach; system-multiplier approach; system-normative approach; system regime of economy; system-dynamic approach. Having studied the monograph, it may be concluded that system-normative and system-program approaches were used to elaborate the Program of Socio-Economic Development of Dubna as a naukograd of the Russian Federation. The Program contains social targets providing for achievement of a special level of the social system, Program implementation period and sources of financing. In order to improve quality of programs it is necessary to assess them, that will enable to find out their advantages and/or disadvantages on different stages, as well as to ensure timely and proper adjustment.

The SED municipal program is to be analyzed according to the main assessment criteria based on the following stages [7]: structure and internal consistency. Thus, we pass to the qualitative analysis of the Program of Socio-Economic Development of Dubna as a naukograd of the Russian Federation 2012-2016.

\section{Program structure analysis}

Analytical part includes characteristics of economic and geographical position of the town, its socioeconomic status, and the key results 
of the Program of Socio-Economic Development of Dubna as a naukograd of the Russian Federation 2008-2013.

The forecast of the Program includes basic lines of complex SED of the town and target values of key indicators of the Program of Socio-Economic Development of Dubna as a naukograd of the Russian Federation 2013-2017.

Competitiveness of the town and possible effect of environment, determining municipal development conditions, are not assessed in the Program. External challenges and threats for the municipality, aggregate potential and opportunities of the town are not identified.

A SWOT analysis enabling to make recommendations on the most effective way of using strengths and neutralization of weaknesses of the municipality was not carried out at Program elaboration. The Program does not include its implementation arrangements: program management, monitoring and evaluation. There are no arrangements to adjust Program activities. The Program contains no resource provision forecast. Extent of financing is fixed at budgeting for the following financial year on the basis of relevant budget opportunities. Thus, the author offers to reach program consistency, and then to implement it stepwise. Namely:

\section{Program internal consistency}

\section{Adequacy (conformance of initial conditions with the main} (strategic) goal and priorities of municipal economic and social development).

The Program offers the innovation strategy as a basis for town development. The innovation strategy provides for establishment of the Dubna science park, which is among the projects for formation of growth areas in the country due to intensification of innovation activity based on naturally interacting basic modules: territorial scientific and technological clusters; innovation belt around JINR and other scientific and engineering organizations of the town; University "Dubna" as a in- 
novation-educational center of the naukograd; IT science park Russian Programming Center; Technology Innovative SEZ. Dubna economic priorities are as follows: development of information and telecommunication infrastructure, innovation infrastructure and research-and-production complex. Besides, the Program underlines development and implementation of the recreational potential of the town.

At the same time, elaboration and realization of the youth policy, formation of positive environment for entrepreneurship are not singled out as the main development lines. Today, only innovation projects are supported in the town. So, it's necessary to support not only innovation projects, but other submitted projects as well, primarily concerning the household sphere. One of the main tasks of forming positive environment for entrepreneurship is to create conditions stimulating the youth to do business.

Ecologic problems also are not among the main lines of complex SED of the town, although Dubna has a potentially dangerous object. JINR constitutes a danger of disastrous radiation pollution. Dubna is a flood-prone area due to the Ivankovo hydroelectric dam. Although official unemployment in Dubna has been growing since 2004, the Program has no measures to solve this problem. Besides, the Program does not contain such chapter as Investment Activity that includes a list of attractive investment projects holding information on number of working places, calculation of economic efficiency of the project, estimated production volume, payments into the budget, profitability and returns.

Thus, the Program places a premium on development of the scientific and innovation potential of the town. Status of the town "naukograd" promotes it. But, the naukograd Program at the same time is the complex SED Program of the town. It determines conditions for developing such spheres as: social, housing and community amenities, health service, culture, sport. Unfortunately, at present these lines of development are considered as supporting ones in Dubna. 


\section{Logic}

Municipal SED goals and tasks, first, are to make allowance for the strategic direction, set in the regional Program, second, to be oriented at global problems and situations of municipal SED.

The Program is to contain logically successive interconnected elements: "strategic directions, tasks to achieve and solve them, activities, effective results that are not only expected but estimated as well". It is the principal condition of Program efficiency [7].

In the Program the logic chain is broken due to lack of activities to achieve some tasks. Thus, for example, one of the key tasks of the Program is a stable growth of the taxation basis of all budgets, but there are no factors and activities stimulating this growth. One more task is to keep world leadership in scientific, scientific and technological and innovation activities, experimental development, trials and staff training being the priorities for the town. Nevertheless, as it was already mentioned above, the Program has no analysis of competitive environment, opportunities and external threats. Foreign economic activity is not determined as a line of development.

The Program does not consider development of a staffing system at enterprises of the scientific-and-production complex and the special economic zone, although this task was specified as a priority.

Program activities are insufficiently worked over many priorities, such as culture, informatization and telecommunication, commerce and services, development of the recreational potential of the territory.

Program activities financing plan is insufficiently thrashed out. It resulted in a discrepancy between some planned and actual values.

In 2012 the Development Strategy 2013-2017 was adopted in the town. Now, we can state that priority directions and specific activities, fixed in the Strategy, differ from the ones, fixed in the current Development Program. 


\section{Relevancy}

In the course of Program implementation it is necessary to evaluate correspondence of indicators to the stated goals. That's why it is needed to find out, if conditions are fulfilled to achieve the system indicators, namely, timely and full information provision, but minimum interim values and indicators.

For the last four years the Program has not been sufficiently amended, and as a result we can see a divergence between some planned and actual values.

In order to assess the Program efficiency it is offered to analyze target values of SED key indicators, fixed in the Program, comparing them with the actual figures for the given years (Table 1). In our country transition to the market economy started in 1990. Before, the longterm planning based on extrapolation was practiced in the country. Nowadays, we can see a transition to the strategic planning enabling business and municipal entities to adapt to the quickly changing external environment and to make full use of their potential.

Analysis results show the feasibility of the SED indicators forecast, fixed in the Program. In 2012 we could see a minimum positive effect of program activities; in 2014 the effect was negative and equaled -5 of possible +11 .

While planning municipal SED, first of all, local potential and production capabilities are taken into account. At that, a market analysis and investigation of its dynamics are nearly non-existent. Managerial staff often does not see the difference between strategic and long-term planning. If it is a long-term program, that is, valid for 5 years and more, it becomes a strategic one without a substantial correspondence with this notion. And strategic planning is understood as development and implementation of similar development programs. Besides, the problem is that in Russia almost there are no regulations of systemic character in strategic planning. In the Dubna Program there is no system monitoring of the external environment and the market. As a 
result, in the course of implementation the Program is not amended according to the changing conditions of development.

Table 1.

Analysis of target values of key social indicators,

Dubna, 2012 and $2014[4,5,6]$

\begin{tabular}{|c|c|c|c|c|c|c|c|c|c|}
\hline \multirow[b]{3}{*}{ Performance Indicators } & \multirow[b]{3}{*}{ Units } & \multicolumn{4}{|c|}{2012} & \multicolumn{4}{|c|}{2014} \\
\hline & & \multicolumn{4}{|c|}{ Performance Indicator Values } & \multicolumn{4}{|c|}{ Performance Indicator Values } \\
\hline & & 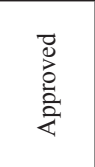 & 总 & 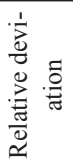 & $\begin{array}{l}\stackrel{0}{\Xi} \\
:\end{array}$ & 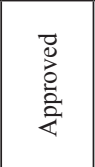 & 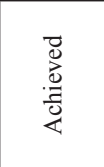 & 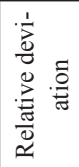 & : \\
\hline $\begin{array}{l}\text { RF tax revenue } \\
\text { from the taxpayers } \\
\text { registered in Dubna }\end{array}$ & $\begin{array}{l}\text { Mln. } \\
\text { RUB }\end{array}$ & 1642.1 & 2702.6 & 1.646 & +1 & 1966.0 & 2640.0 & 1.343 & +1 \\
\hline $\begin{array}{l}\text { Resident population } \\
\text { (average annual) }\end{array}$ & $\begin{array}{l}\text { Thous. } \\
\text { people }\end{array}$ & 68950 & 62534 & 0.907 & -1 & 71000 & 65400 & 0.921 & -1 \\
\hline $\begin{array}{l}\text { Average salary } \\
\text { in the town }\end{array}$ & $\begin{array}{l}\text { RUB/ } \\
\text { month }\end{array}$ & 17826.0 & 16148.64 & 0.906 & -1 & 24395.0 & 17410.26 & 0.714 & -1 \\
\hline Retail turnover & $\begin{array}{l}\text { Mln. } \\
\text { RUB }\end{array}$ & 3551.4 & 4532.9 & 1.276 & +1 & 4831.7 & 5544.3 & 1.147 & +1 \\
\hline $\begin{array}{l}\text { Paid services } \\
\text { to the general public }\end{array}$ & $\begin{array}{l}\text { Mln. } \\
\text { RUB }\end{array}$ & 1500.0 & 1605.72 & 1.070 & +1 & 2120.0 & 1758.39 & 0.829 & -1 \\
\hline $\begin{array}{l}\text { Average housing } \\
\text { per capita }\end{array}$ & $\begin{array}{c}\text { Sq.m/ } \\
\text { man }\end{array}$ & 21.7 & 23.85 & 1.099 & +1 & 23.4 & 24.14 & 1.032 & +1 \\
\hline $\begin{array}{c}\text { Commissioning } \\
\text { of residential houses } \\
\text { built due to all sources } \\
\text { of finance }\end{array}$ & $\begin{array}{l}\text { Thous. } \\
\text { sq.m }\end{array}$ & 65.00 & 54.4 & 0.837 & -1 & 90.0 & 68.0 & 0.756 & -1 \\
\hline Residential floor area & $\begin{array}{l}\text { Thous. } \\
\text { sq.m }\end{array}$ & 1501.51 & 1490.9 & 0.923 & -1 & 1666.51 & 1579.0 & 0.947 & -1 \\
\hline $\begin{array}{l}\text { Employment } \\
\text { in economy }\end{array}$ & person & 37100 & 33460.0 & 0.902 & -1 & 38600 & 32500 & 0.842 & -1 \\
\hline $\begin{array}{l}\text { Total salary budget } \\
\text { in the town }\end{array}$ & $\begin{array}{l}\text { Mln. } \\
\text { RUB }\end{array}$ & 5530.0 & 6484.0 & 1.173 & +1 & 7830.0 & 6790.0 & 0.867 & -1 \\
\hline $\begin{array}{l}\text { Fixed investment } \\
\text { due to all sources (bud- } \\
\text { get allocations for the } \\
\text { special economic zone } \\
\text { excluding) }\end{array}$ & $\begin{array}{l}\text { Mln. } \\
\text { RUB }\end{array}$ & 4315.5 & 4812.6 & 1.115 & +1 & 6183.9 & 4464.8 & 0.722 & -1 \\
\hline TOTAL & & & & & +1 & & & & -5 \\
\hline
\end{tabular}




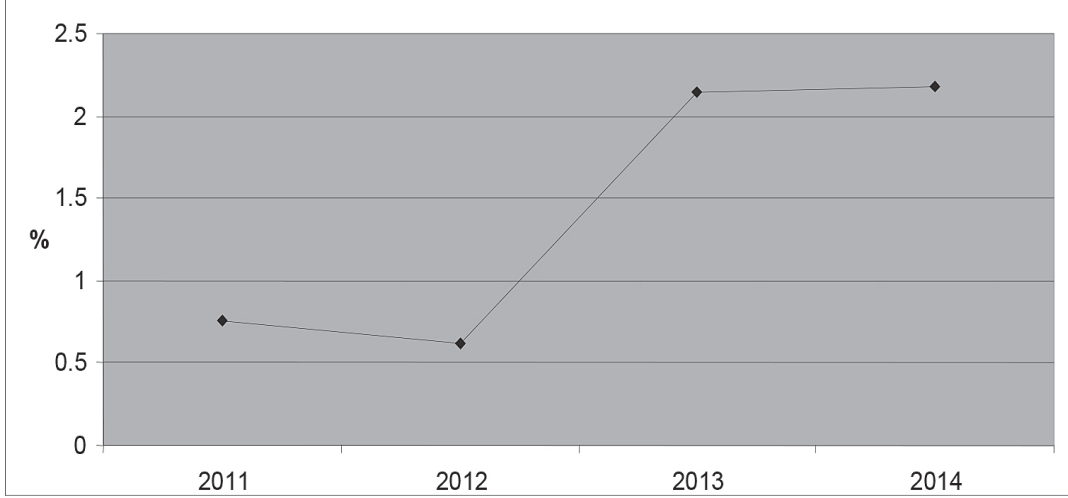

Fig. 1. Recorded unemployment 2011-2014, \% [4]

Development indicators, fixed in the Program, and yearly performance indicators are inconsistent. Thus, it is necessary to elaborate the unified SED indicator system in order to analyze efficiency and performance of program activities, adjust goals and methods for their achievement. In spite of the fact that tax revenues are growing yearly, a lot of SED indicators, for example, recorded unemployment, availability of preschool facilities, have a reverse dynamics.

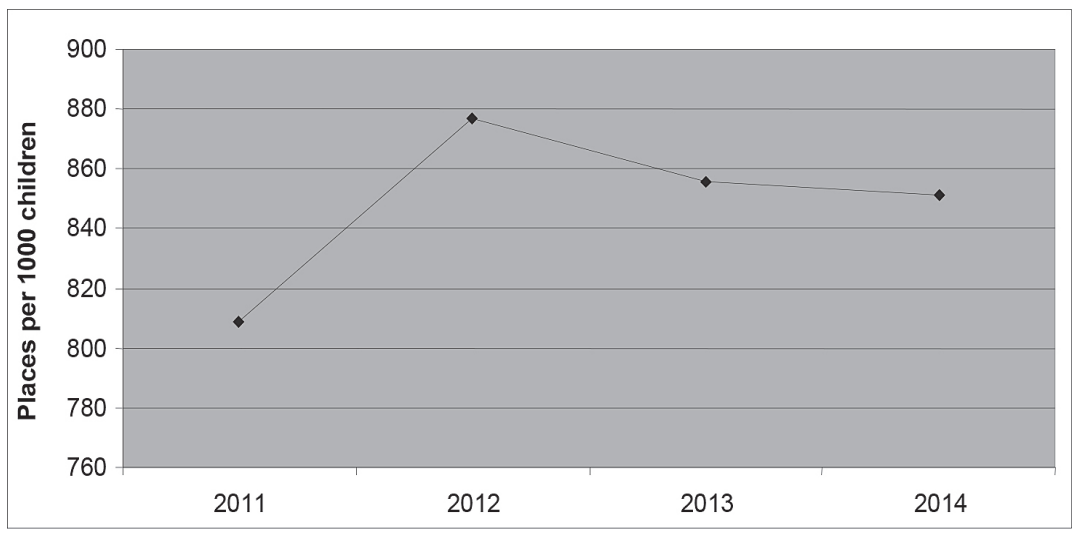

Fig. 2. Availability of preschool facilities, 2011-2014 (places per 1000 preschool children) [4] 
Table 2.

Calculation of municipal social indicators

\begin{tabular}{|c|c|c|}
\hline Indicator and area for improvement & Formula & Value \\
\hline \multicolumn{3}{|l|}{ Goal: Economic development. } \\
\hline 1. Production volume per capita & $F 1=V t / Y_{t}$ & 231.630 \\
\hline 2. Production growth rate & $F 2=(V t-V t-1) V t$ & 1.099 \\
\hline $\begin{array}{l}\text { 3. Small business development level as a ratio } \\
\text { of population employed in small business to } \\
\text { total economically active population }\end{array}$ & $F 3={ }^{\mathrm{Y}} \mathrm{t}^{\prime} / \mathrm{\Psi}_{t}$ & 0.278 \\
\hline 4. Share of profit-making companies & $F 4=\Pi t(+) / \Pi t$ & 0.857 \\
\hline $\begin{array}{l}\text { 5. Total internal investment resources as a sum } \\
\text { of depreciation and profit remaining at the dis- } \\
\text { posal of local enterprises per capita }\end{array}$ & /Yt & 219.198 \\
\hline \multicolumn{3}{|l|}{ Goal: Social development. } \\
\hline $\begin{array}{l}\text { 6. Living standards of population as a ratio of } \\
\text { average money income and income in kind (in } \\
\text { value terms) per capita }\end{array}$ & $4 t$ & 0.291 \\
\hline 7. Number of cars per population (per 1000 men) & $F 7=1000 \mathrm{At} / \mathrm{Yt}$ & 367 \\
\hline 8. Availability of landline (per $1000 \mathrm{men}$ ) & $F 8=1000 \mathrm{Tt} / 4 \mathrm{t}$ & 798 \\
\hline 9. Availability of hard roads & $F 9=W t /(\operatorname{sqrt} \varphi j S j)$ & 0.042 \\
\hline 10. Paid services for populations (per capita) & $F 10=U t / 4 t$ & 25.637 \\
\hline \multicolumn{3}{|l|}{ Goal: Ecologization of the territory } \\
\hline 11. Pollution level & 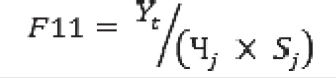 & 23.601 \\
\hline $\begin{array}{l}\text { 12. Accumulated anthropogenic change of the } \\
\text { territory evaluated by the town natural protec- } \\
\text { tion factor }\end{array}$ & $\begin{array}{c}F 12=(S j 1+0,8 S j 2+0,6 S \\
j 3+0,4 S j 4+0,2 S j 5) / S j \\
\mathrm{~S} \mathrm{j} 1-\text { wooded lands, } \\
\mathrm{S} \mathrm{j} 2 \text { - trees and shrubs } \\
\text { lands falling outside the } \\
\text { forest fund, } \mathrm{S} \text { j3 - swamps, } \\
\mathrm{S} \mathrm{j} 4 \text { - agricultural lands, } \\
\mathrm{S} \mathrm{j} 5 \text { - underwater lands. }\end{array}$ & 0.492 \\
\hline
\end{tabular}

In order to determine the development priority, calculations set forth in Table 2 should be made [8].

Then, we scale the indicators and calculate the arithmetical average of the indicators by goals.

Economic development: 0.0906.

Social development: 0.2380 .

Ecologization of the territory: 0.0112 . 
In the furtherance of identified issues the author offered to form a working group on the basis of the Department of Public Administration at the University "Dubna", which would cooperate with the town administration on elaboration of the next SED program. Functions of a working group: SWOT, STEP, ETOM analyses of the municipal formation Dubna Urban District; determination of the town cumulative potential and its competitive advantages; elaboration of the system of SED indicators to forecast and monitor Program implementation, all plan documents of the town; determination of the Program structure; coordination of Program activities with town priorities. At the moment, these offers are admitted to examination by the town administration.

\section{Conclusion}

- Medium-term planning is the basic planning in Dubna.

Qualitative assessment of the SED Program enabled to find out the following weaknesses of the Program. A SWOT analysis was not carried out at Program elaboration. There is no evaluation of town competitiveness and possible external influence. The Program does not include its implementation arrangements and arrangements to adjust Program activities. The Program contains no resource provision forecast. The Program places a premium on development of the scientific and innovation potential of the town. At that, it does not provide activities on some areas of concern, such as decline in unemployment, implementation of the youth policy, etc. As a result, the logic chain "priorities-tasks-program activities-expected results" is broken. Program activities and their financing plan are insufficiently worked over such priorities as culture, informatization and telecommunication. It resulted in a discrepancy between some planned and actual values.

- Based on the comparative analysis of the Development Strategy 2013-2017, adopted in 2012, and the Development Program we can state that priority directions and specific activities, fixed in the Strategy, differ from the ones, fixed in the current Development Program. 
- Target values of SED key indicators for 2012 and 2014 have been analyzed. In 2012 we could see a minimum positive effect of program activities; in 2014 the effect was negative and equaled -5 .

- The current Dubna Program is not a strategic one. There is no system monitoring of the external environment and the market. As a result, in the course of implementation the Program is not amended according to the changing conditions of development.

- Development indicators, fixed in the Program, and yearly local government performance indicators are inconsistent.

- In spite of the fact that tax revenues are growing yearly, a lot of SED indicators, for example, recorded unemployment, availability of preschool facilities, have a reverse dynamics.

- Following the SED Program analysis, the author offered to form a working group of teachers and students on the basis of the Department of Public Administration, which would cooperate with the town administration on elaboration of the next SED program, namely: SWOT, STEP, ETOM analyses of the municipal formation Dubna Urban District; determination of the town cumulative potential and its competitive advantages; elaboration of the system of SED indicators to forecast and monitor Program implementation; determination of the Program structure; coordination of Program activities with town priorities.

- The research resulted in identification of instruments and directions for improving the system of indicators to assess priorities of the municipal SED Program, to evolve its implementation strategy and algorithm that will finally produce a synergetic effect.

\section{References}

1. Information and reference material on the socio-economic development of Dubna 2004-2016.

2. Kukushkina V.V. Modeli i metody strategicheskogo planirovaniya $i$ razvitiya [Models and methods of strategic planning and development]. Moscow: VINITI, 1999. P. 242. 
3. Nekhaev S.A. Formirovanie programm sotsial'no-ekonomicheskogo razvitiya regionov Rossii v usloviyakh globalizatsii mirovoy ekonomiki [Elaboration of SED programs for Russian regions in the age of the world economic globalization]. FINANSY.RU. 2004.

4. The Mayor's performance report for 2006-2014.

5. SED forecasts 2011-2016.

6. SED Program of Dubna as a naukograd for 2011-2015.

7. Roshchina I.V. Grinkevich L.S. Skvoznoy integrirovannyy podkhod $\mathrm{k}$ otsenke programm sotsial'no-ekonomicheskogo razvitiya territoriy [End-to-end integrated approach to estimation of the programs of social-economic development of territories]. Vestnik Tomskogo gosudarstvennogo universiteta [Tomsk State University Journal of Economics]. 2008. №. 3(4).

8. The development strategy of the city on 2013-2017.

9. Regional planning as an important element of the system of strategic planning and forecasting of development of the Russian Federation and municipal formations. Information Analysis Department of the State Council of the Republic of Adygea. 2009. http://www.gshra.ru/main/socially/.

10. Shamalov Yu.N. Ekonomicheskoe obosnovanie programmy sotsial'noekonomicheskogo razvitiya regiona (na primere Khanty-Mansiyskogo avtonomnogo okruga) [The economic rationale of the program of socio-economic development of the region (on the example of KhantyMansiysk Autonomous Okrug)]. Moscow, 2007.

\section{Список литературы}

1. Информационно-справочный материал о социально-экономическом развитии г. Дубны в 2004-2016 гг.

2. Кукушкина В.В. Модели и методы стратегического планирования и развития. М.: ВИНИТИ, 1999. 242 с.

3. Нехаев С.А. Формирование программ социально-экономического развития регионов России в условиях глобализации мировой экономики // ФИНАНСЫ.RU. 2004. 
4. Отчеты Главы города об итогах работы за 2006-2014 гг.

5. Прогнозы социально-экономического развития 2011-2016 гг.

6. Программа социально-экономического развития г. Дубны как наукограда РФ на 2011-2015 гг.

7. Рощина И.В. Гринкевич Л.С. Сквозной интегрированный подход к оценке программ социально-экономического развития территорий // Вестник Томского государственного университета. 2008. № 3(4).

8. Стратегия развития города на 2013-2017 гг.

9. Территориальное планирование как важный элемент системы стратегического планирования и прогнозирования развития Российской Федерации и муниципальных образований // Информационно-аналитическое управление Аппарата Государственного Совета-Хасэ Республики Адыгея. 2009. http://www.gshra.ru/main/socially/

10. Шамалов Ю.Н. Экономическое обоснование программы социально-экономического развития региона (на примере Ханты-Мансийского автономного округа): автореферат. М., 2007.

\section{DATA ABOUT THE AUTHOR}

Yankovskaya Veronica Vladimirovna, Candidate of Economic Sciences, Associate Professor, Department of Theory of Management and Business Technologies

Plekhanov Russian University of Economics

36, Stremyanny lane, Moscow, 117997, Russian Federation managreu@gmail.com

\section{ДАННЫЕ ОБ АВТОРЕ}

Янковская Вероника Владимировна, кандидат экономических наук, доцент

Российский экономический университет им. Г.В. Плеханова Стремянный переулок, 36, г. Москва, 117997, Российская Федераичия managreu@gmail.com 